\title{
Association of varicella zoster virus load in the aqueous humor with clinical manifestations of anterior uveitis in herpes zoster ophthalmicus and zoster sine herpete
}

\author{
S Kido, ${ }^{1}$ S Sugita, ${ }^{1}$ S Horie, ${ }^{1}$ M Miyanaga, ${ }^{2} \mathrm{~K}$ Miyata, ${ }^{2} \mathrm{~N}$ Shimizu, ${ }^{3} \mathrm{~T}$ Morio, ${ }^{4}$ \\ M Mochizuki'
}

${ }^{1}$ Department of Ophthalmology \& Visual Science, Tokyo Medical and Dental University, Tokyo, Japan; ${ }^{2}$ Miyata Eye Hospital, Miyakonojyo, Japan;

${ }^{3}$ Department of Virology, Medical Research Institute,

Tokyo Medical and Dental University, Tokyo, Japan:

${ }^{4}$ Center for Cell Therapy, Tokyo Medical and Dental University, Tokyo, Japan

Correspondence to:

Dr S Sugita, Department of Ophthalmology \& Visual Science, Tokyo Medical and Dental University Graduate School of Medicine, 1-5-45 Yushima, Bunkyo-ku, Tokyo 113-8519, Japan; sunaoph@tmd.ac.jp

Accepted 4 August 2007 Published Online First

1 February 2008

\section{ABSTRACT}

Aim: To investigative whether clinical manifestations of anterior uveitis are associated with the viral load of varicella zoster virus (VZV) in the aqueous humor in patients with herpes zoster ophthalmicus (HZO) and zoster sine herpete (ZSH).

Methods: After informed consent was given, an aliquot of aqueous humor was collected from patients with VZV anterior uveitis $(n=8)$. Genomic DNA of the human herpes viruses was measured in the aqueous humor by two PCR assays: a qualitative multiplex PCR and a quantitative real-time PCR.

Results: All patients had unilateral acute anterior uveitis with high intraocular pressure, mutton fat keratic precipitates with some pigmentation, and trabecular meshwork pigmentation. Multiplex PCR demonstrated VZV genomic DNA in all of the samples, but not in other human herpes virus samples (human simplex virus types 1 and 2, Epstein-Barr virus, cytomegalovirus and human herpes virus types 6, 7 and 8). Real-time PCR revealed a high copy number of VZV DNA in the aqueous humor. After the initial onset of anterior uveitis, iris atrophy and distorted pupil with paralytic mydriasis developed. The intensity of iris atrophy and pupil distortion, but not ocular hypertension, correlated with the viral load of VZV in the aqueous humor.

Conclusion: VZV viral load in the aqueous humor correlated significantly with damage to the iris (iris atrophy and pupil distortion) in patients with HZO and ZSH.

Varicella zoster virus (VZV) affects the first branch of the trigeminal nerve and is known to cause unilateral anterior uveitis (VZV anterior uveitis) characterised by mutton-fat keratic precipitates (KPs), trabecular meshwork pigmentation, ocular hypertension, iris atrophy and distorted pupil. Systemic signs in VZV iridocyclitis can be herpes zoster ophthalmicus (HZO) with skin eruptions or zoster sine herpete ( $\mathrm{ZSH}$ ) without skin eruptions but solely with neuralgia. Using PCR, previous studies have revealed genomic DNA of VZV in the aqueous humor in patients with anterior uveitis with $\mathrm{HZO}$ and ZSH. ${ }^{12}$ Recent advances in molecular biology now make it possible for quantitative measurement of the viral load using real-time PCR. Therefore, this study aimed to quantitatively measure the viral load of VZV in the aqueous humor and analyse the correlation between viral load in the aqueous humor and clinical manifestations of VZV anterior uveitis in patients with $\mathrm{HZO}$ and $\mathrm{ZSH}$.

\section{MATERIALS AND METHODS \\ Subjects}

The subjects were eight patients (three men and five women; age range 43-71 years (mean 61)) with diagnosed VZV anterior uveitis at Tokyo Medical and Dental University Hospital and Miyata Hospital between December 1999 and September 2007. The clinical diagnosis of VZV anterior uveitis was based on observation of anterior uveitis associated with either $\mathrm{HZO}$ or ZSH. After informed consent had been obtained, an aliquot of aqueous humor (0.1-0.2 ml) was obtained from each patient. The research followed the tenets of the Declaration of Helsinki, and the study was approved by the institutional ethics committees of Tokyo Medical and Dental University.

\section{PCR assay}

The aqueous humor samples were centrifuged at $3000 \mathrm{rpm}$ for $5 \mathrm{~min}$ and used for the following PCR assays: multiplex PCR and real-time PCR. ${ }^{3}$ Multiplex PCR was designed to qualitatively measure the genomic DNA of eight human herpes viruses: herpes simplex virus type 1 (HSV-1) and type 2 (HSV-2), VZV, Epstein-Barr virus (EBV), cytomegalovirus (CMV), human herpes virus type 6 (HHV-6), type 7 (HHV-7) and type 8 (HHV-8). DNA was extracted from the aqueous humor samples using a DNA minikit (Qiagen, Valencia, CA, USA). Multiplex PCR was performed using LightCycler (Roche, Basle, Switzerland). The primer sequences and PCR conditions for VZV were as previously described. ${ }^{4}$

Real-time PCR was performed only for HHV, the genomic DNA of which was detected by multiplex PCR. It was performed by using Amplitaq Gold and a Real-Time PCR 7300 system (ABI, Forster City, CA, USA). The primer sequences for VZV (ORF29) used in real-time PCR were designed to use Primer Express (ABI): forward, AACTTTTACATCCAGCCTGGCG; reverse, GAAAACCCAAACCGTTCTCGAG. The probe was FAM-TGTCTTTCACGGAGGCAAACACGT-TAMRA. The following PCR conditions were used: denaturation at $95^{\circ} \mathrm{C}$ for $10 \mathrm{~min}, 95^{\circ} \mathrm{C}$ for $15 \mathrm{~s}$, and $60^{\circ} \mathrm{C}$ for $60 \mathrm{~s}$ for 40 cycles. 
Table 1 Clinical findings at initial presentation in patients with varicella zoster virus (VZV) anterior uveitis

\begin{tabular}{|c|c|c|c|c|c|c|c|c|c|c|c|c|c|}
\hline \multirow[b]{2}{*}{ Case } & \multirow[b]{2}{*}{$\begin{array}{l}\text { Age } \\
\text { (years) }\end{array}$} & \multirow[b]{2}{*}{ Sex } & \multirow[b]{2}{*}{ Eye } & \multicolumn{5}{|c|}{ Initial ocular findings } & \multirow{2}{*}{$\begin{array}{l}\text { Pigmentation } \\
\text { in the AC } \\
\text { angle }\end{array}$} & \multirow[b]{2}{*}{ Eruption } & \multirow{2}{*}{$\begin{array}{l}\text { Time from } \\
\text { onset to } \\
\text { treatment }\end{array}$} & \multicolumn{2}{|c|}{ Herpes virus DNA } \\
\hline & & & & VA & $\begin{array}{l}\text { IOP } \\
(\mathrm{mm} \mathrm{Hg})\end{array}$ & $\begin{array}{l}\text { Mutton- } \\
\text { fat KPs }\end{array}$ & $\begin{array}{l}\text { Cells } \\
\text { in AC }\end{array}$ & $\begin{array}{l}\text { Flare } \\
\text { in AC }\end{array}$ & & & & VZV & Others* \\
\hline 1 & 67 & $\mathrm{~F}$ & Left & 0.3 & 38 & + & $3+$ & 271 & Wide & - & 2 months & + & - \\
\hline 3 & 68 & $\mathrm{~F}$ & Right & 0.8 & 10 & + & $2+$ & 34 & None & - & 2 months & + & - \\
\hline 4 & 56 & M & Left & 1.2 & 46 & + & $3+$ & 241 & Partial & + & 2 months & + & - \\
\hline 5 & 70 & $\mathrm{~F}$ & Left & 1.2 & 25 & - & $1+$ & 13 & Partial & - & 2 months & + & - \\
\hline 8 & 71 & M & Right & 0.3 & 28 & - & $2+$ & 13 & None & + & None & + & - \\
\hline
\end{tabular}

Aqueous humor samples from eight cases were analysed for human herpes virus DNA by multiplex PCR.

${ }^{*}$ Herpes viruses excluding VZV, ie, herpes simplex virus type 1 and type 2, Epstein-Barr virus, cytomegalovirus, human herpes virus types 6, 7 and 8.

VA, visual acuity; IOP, intraocular pressure; KPs, keratic precipitates; $A C$, anterior chamber.

\section{Statistical analysis}

Statistical analysis was performed using the Mann-Whitney U test. Statistical significance was set at $\mathrm{p}<0.05$.

\section{RESULTS}

\section{Clinical manifestations}

In four of the patients, there was an episode of skin eruption with neuralgia in the area of the first branch of the trigeminal nerve; this was clinically diagnosed as HZO (table 1). No skin eruptions were observed in the other patients, although they complained of pain near the first branch of the trigeminal nerve, leading to the diagnosis of $\mathrm{ZSH}$. At various intervals after the onset of $\mathrm{HZO}$ or ZSH, the patients developed unilateral anterior uveitis. All patients had cells and flare in the anterior chamber, with increased flare values measured by a laser flare meter (Cowa, Tokyo, Japan). Four patients exhibited mutton-fat KPs (table 1), which had brownish pigmentation and were small or medium in size. Three patients with HZO already exhibited iris atrophy and pupil distortion on referral. High intraocular pressure (IOP) was recorded in all patients except in case 3 (table 1). A gonioscopic examination revealed wide, open angles in all patients, and higher pigmentation in the affected eye than the other eye in six of the eight patients. Ophthalmoscopic examinations revealed no significant inflammatory lesions in the retina and choroid. These clinical results led us to a diagnosis of anterior uveitis associated with $\mathrm{HZO}$ or $\mathrm{ZSH}$, with paracentesis subsequently performed in order to carry out the PCR analysis.

After confirmation of the presence of VZV in the aqueous humor by multiplex PCR, systemic anti-VZV agents (aciclovir or valaciclovir) and aciclovir ointment were administered for at least 4 weeks together with a topical corticosteroid (eg, betamethasone) and anti-glaucoma agents (eg, timolol and latanoprost). Iris atrophy and pupil distortion developed during the clinical course (fig 1, table 2). The anterior uveitis and high IOP responded well to treatment.

\section{PCR analysis of the aqueous humor}

Qualitative PCR (multiplex PCR) detected genomic DNA of VZV but not of other human herpes viruses (HSV-1, HSV-2, EBV, CMV, HHV-6, HHV-7 and HHV-8) in the aqueous humor of all eight patients (table 1). In peripheral blood samples, however, no genomic DNA of any of the eight human herpes viruses, including VZV, was detected in any of the patients.

Quantitative PCR (real-time PCR) detected significant viral loads of VZV DNA in the aqueous humor of the eight patients ranging from $3.8 \times 10^{2}$ to $1.2 \times 10^{7} \mathrm{copies} / \mathrm{ml}$ (table 2). It is of note that the VZV viral load in the aqueous humor correlated with the intensity of iris atrophy and pupil distortion (table 2, fig 1). Patient 1 had the highest VZV viral load $\left(1.2 \times 10^{7}\right.$ copies $\left./ \mathrm{ml}\right)$ in the aqueous humor and also had the most severe iris atrophy, with multiple wide areas of segmental iris atrophy and a widely dilated pupil (fig 1A, table 2). Patients $2-5$ had the second

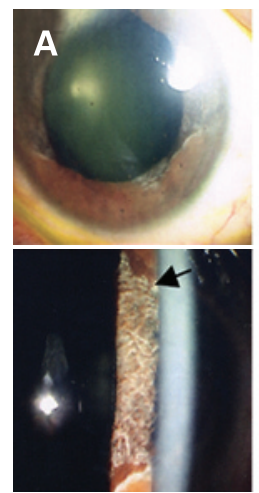

$1.2 \times 10^{7}$ (case 1$)$

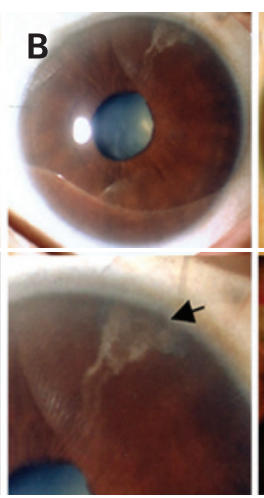

$1.2 \times 10^{6}($ case 2$)$

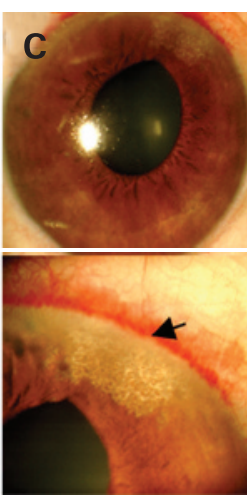

$1.0 \times 10^{6}($ case 3$)$

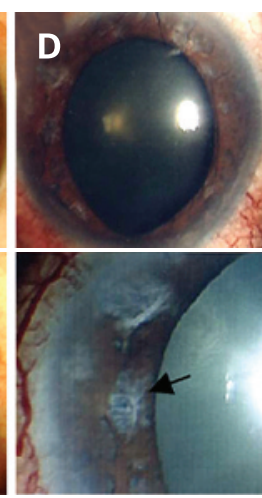

$9.8 \times 10^{5}($ case 4$)$

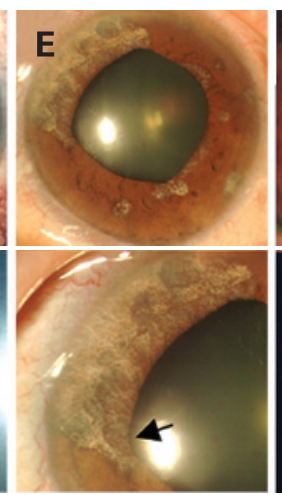

$9.8 \times 10^{5}($ case 5$)$

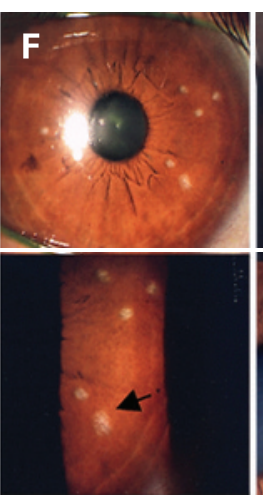

$1.3 \times 10^{5}($ case 6$)$

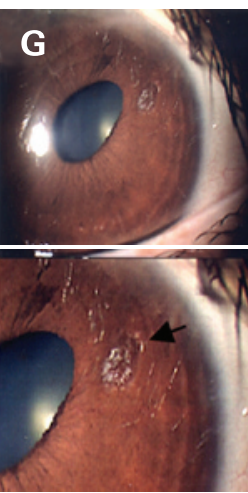

$2.2 \times 10^{4}($ case 7$)$

VZV genomic DNA in aqueous humour (copies/ml)

Figure 1 Iris photographs for patients with varicella zoster virus (VZV) anterior uveitis. Slit-lamp photographs are available for seven cases as shown. The numbers indicate the copies of the VZV genomic DNA for each of the aqueous humor samples (copies/ml). Arrows point to areas of iris atrophy. Consent has been obtained for publication of this figure. 
Table 2 Virological analysis and ocular findings after treatment of patients with varicella zoster virus (VZV) anterior uveitis

\begin{tabular}{|c|c|c|c|c|c|c|c|c|c|c|c|}
\hline \multirow[b]{2}{*}{ Case } & \multirow[b]{2}{*}{$\begin{array}{l}\text { VZV DNA } \\
\text { (copies/ml) }\end{array}$} & \multicolumn{4}{|c|}{ Final ocular findings } & \multirow[b]{2}{*}{ Iris atrophy } & \multirow{2}{*}{$\begin{array}{l}\text { Extent } \\
\text { of iris } \\
\text { atrophy } \\
(\%)\end{array}$} & \multirow[b]{2}{*}{ Pupil } & \multirow{2}{*}{$\begin{array}{l}\text { Maximum } \\
\text { pupil } \\
\text { diameter } \\
(\mathrm{mm})\end{array}$} & \multirow[b]{2}{*}{$\begin{array}{l}\text { Systemic } \\
\text { treatment }\end{array}$} & \multirow[b]{2}{*}{$\begin{array}{l}\text { Follow-up } \\
\text { (months) }\end{array}$} \\
\hline & & VA & $\begin{array}{l}\text { IOP } \\
\text { (mm Hg) }\end{array}$ & $\begin{array}{l}\text { Cells } \\
\text { in AC }\end{array}$ & $\begin{array}{l}\text { Flare } \\
\text { in AC }\end{array}$ & & & & & & \\
\hline 1 & $1.2 \times 10^{7}$ & $\mathrm{~mm}$ & 10 & - & 13 & Wide & 40 & Distorted, mydriasis & 8.1 & ACV, ACZ & 48 \\
\hline 3 & $1.0 \times 10^{6}$ & 0.8 & 7 & - & 5 & Segmental & 15 & Distorted, mydriasis & 5.0 & VCV & 4 \\
\hline 4 & $9.8 \times 10^{5}$ & 0.9 & 10 & - & 73 & Segmental & 20 & Distorted, mydriasis & 7.9 & VCV & 12 \\
\hline 5 & $9.8 \times 10^{5}$ & 0.8 & 20 & - & 22 & Segmental & 29 & Distorted, mydriasis & 7.0 & VCV & 5 \\
\hline 7 & $2.2 \times 10^{4}$ & 2 & 16 & - & 3 & Circular & 1 & Distorted, mild mydriasis & 4.3 & VCV & 13 \\
\hline 8 & $3.8 \times 10^{2}$ & 1.2 & 12 & - & 9 & None & 0 & Normal & 2.6 & ACV, ACZ & 4 \\
\hline
\end{tabular}

The copy number of the VZV genome in aqueous humor was evaluated with real-time PCR. The extent of iris atrophy was calculated using Photoshop Elements V2.0. ACV, aciclovir; ACZ, acetazolamide; mm, motus manus; VCV, valaciclovir.

highest viral loads in the aqueous humor $\left(\sim 1 \times 10^{6}\right.$ copies $\left./ \mathrm{ml}\right)$, and these patients developed multiple segmental or circular iris atrophy with moderate pupil distortion, although these signs were not as marked as in patient 1 (fig $1 \mathrm{~B}-\mathrm{E}$, table 2). Patients 6 and 7 had the third highest viral load $\left(10^{5}-10^{4}\right.$ copies $\left./ \mathrm{ml}\right)$ and exhibited circular iris atrophy with minimum pupil distortion (fig $1 F, G$ ). Patient 8 had the lowest viral load. This patient exhibited no iris atrophy and the pupil remained normal throughout the clinical course.

We next examined whether higher viral load in the aqueous humor was significantly associated with the intensity of the iris atrophy and pupil distortion. For this analysis, we separated the patients into two groups: higher viral load (patients 1-5) and lower viral load (patients 6-8). The extent of iris atrophy was significantly $(p<0.05)$ larger in the group with higher viral load. In addition, the maximum pupil diameter in the pupil distortion was significantly $(p<0.05)$ larger in the group with higher viral load. These results suggest that higher viral load in the aqueous humor is closely associated with the intensity of the iris atrophy and pupil distortion.

\section{DISCUSSION}

Human herpes viruses are known to be involved in many ocular pathological conditions, such as keratitis, anterior uveitis and necrotising retinitis. Early treatment with anti-viral agents, based on a rapid and accurate diagnosis of the viral infection in ocular tissues, is clinically important in order to avoid the irreversible tissue damage and visual impairment caused by viral infection. Recent advances in PCR methodology have made it possible to screen for viral infection and further quantify the intensity of the viral infection in ocular inflammatory diseases. ${ }^{1-}$ ${ }^{35-8}$ Asano et al ${ }^{8}$ detected herpes virus DNA (VZV or HSV-2) in three cases of acute retinal necrosis using real-time PCR. They monitored viral load in ocular samples of these patients and examined correlations with disease activities of acute retinal necrosis. In this study, we used multiplex PCR to screen for HHV infections (HHV1-8) and real-time PCR to quantify viral load in the aqueous humor of patients with $\mathrm{HZO}$ or ZSH.

With multiplex PCR, genomic DNA of VZV was detected in the aqueous humor of all eight patients with $\mathrm{HZO}$ and $\mathrm{ZSH}$, and significant VZV viral loads were quantified in the same samples with real-time PCR. After cutaneous lesions or neuralgia, all eight patients with $\mathrm{HZO}$ or ZSH developed anterior uveitis, which was characterised by unilateral acute anterior uveitis with high IOP, mutton-fat KPs, trabecular meshwork pigmentation, iris atrophy and pupil distortion, although there were no significant pathological lesions in the cornea or ocular fundus of any of the patients. It is well established that these ocular signs are typical of $\mathrm{HZO}$. The present multiplex PCR data clearly confirm that VZV, but not the other human herpes viruses, is responsible for the anterior uveitis. Furthermore, an important finding in our study was that the extent of iris atrophy and pupil distortion also correlated with the viral load of VZV in the aqueous humor in patients with $\mathrm{HZO}$ and ZSH. Unlike iris atrophy, IOP did not correlate with the viral load in the aqueous humor. All but one of the patients had raised IOP ranging from 22 to $46 \mathrm{~mm} \mathrm{Hg}$ at the onset of anterior uveitis.

This study did not reveal any pathological mechanisms for the correlation of the high VZV viral load with the iris atrophy. However, a previous immunohistological report detected VZV antigens in the stroma and vascular endothelial cells of the iris in anterior uveitis patients with HZO. ${ }^{9}$ Another study that used angiography in a patient with $\mathrm{HZO}$ showed that there was occlusion of the blood vessels of the atrophic iris. ${ }^{10}$ On the basis of previous studies and our present data, we hypothesise that the pathological changes caused by VZV may induce occlusion of the iris vessel leading to iris muscle paralysis, with a net result of iris atrophy and pupil distortion. The higher the viral load in the anterior chamber, the more VZVs there will be in the iris, and thus the more intense the pathological tissue damage.

Early initiation of systemic anti-viral agents, as guided by PCR analysis, would help to avoid, or at least minimise, tissue damage in the iris. Some patients with HZO were only given 1week systemic anti-viral treatments after the onset of the skin lesions. In these patients, the viral loads of VZV in the aqueous humor were high, and various degrees of iris atrophy and distorted pupil were seen over time. These observations suggest that systemic anti-viral treatments after the onset of $\mathrm{HZO}$ are helpful in avoiding or minimising irreversible ocular complications and that qualitative and quantitative PCR can also provide useful information for developing treatments for such patients.

Acknowledgements: We thank Drs Ken Watanabe and Miki Mizukami for technical assistance. This work was supported by a Grant-in-Aid for Young Scientists (B) 18791263 from the Ministry of Education, Culture, Sports, Science and Technology, Japan.

Competing interests: None declared.

Ethics approval: Ethics approval was obtained.

Patient consent: Consent has been obtained for publication of fig 1.

\section{REFERENCES}

1. Yamamoto S, Tada R, Shimomura $Y$, et al. Detecting varicella-zoster virus DNA in iridocyclitis using polymerase chain reaction. Arch Ophthalmol 1995;113:1358-9.

2. Nakamura N, Tanabe M, Yamada Y, et al. Zoster sine herpete with bilateral ocular involvement. Am J Ophthalmol 2000;129:809-10. 
3. Sugita S, Shimizu N, Kawaguchi T, et al. Identification of human herpesvirus 6 in a patient with severe unilateral panuveitis. Arch Ophthalmol 2007125:1426-7.

4. Espy MJ, Teo R, Ross TK, et al. Diagnosis of varicella-zoster virus infections in the clinical laboratory by LightCycler PCR. J Clin Microbiol 2000;38:3187-9.

5. De Schryver I, Rozenberg N, Cassous S, et al. Diagnosis and treatment of cytomegalovirus iridocyclitis without retinal necrosis. Br J Ophthalmol 2006;90:852-5.

6. Koizumi N, Yamasaki K, Kawasaki $S$, et al. Cytomegalovirus in aqueous humor from an eye with corneal endotheliitis. Am J Ophthalmol 2006;141:564-5.
7. Tran TH, Rozenberg F, Cassoux N, et al. Polymerase chain reaction analysis of aqueous humor samples in necrotising retinitis. Br J Ophthalmol 2003:87:79-83.

8. Asano S, Yoshikawa $\mathrm{T}$, Kimura $\mathrm{H}$, et al. Monitoring herpesvirus DNA in three cases of acute retinal necrosis by real-time PCR. J Clin Virol 2004;29:206-9.

9. Nakashizuka H, Yamazaki Y, Tokumaru M, et al. Varicella-zoster viral antigen identified in iridocyclitis patient. Jpn J Ophthalmol 2002;46:70-3.

10. Marsh RJ, Easty DL, Jones BR, et al. Iritis and iris atrophy in herpes zoster ophthalmicus. Am J Ophthalmol 1974;78:255-61.

\section{FUNDING AVAILABLE FOR RESEARCH PROJECTS}

The Committee on Publication Ethics (COPE) has established a Grant Scheme to fund research in the field of publication ethics. The Scheme is designed to provide financial support to any member of COPE for a defined research project that is in the broad area of the organisation's interests, and specifically in the area of ethical standards and practice in biomedical publishing. The project should have a specific goal and be intended to form the kernel of a future publication.

A maximum sum of $£ 5000$ will be allocated to any one project, but applications for smaller sums are welcomed.

The terms and conditions of the Grant are as follows:

- At least one of the applicants must be a member of COPE.

- Calls for applications will be made twice a year with closing dates of 1 December and 1 June. An electronic version of the application form must be sent to the Administrator no later than $12 \mathrm{pm}$ (noon GMT) on the closing date for consideration by COPE Council.

- The application must contain a lay summary of the project, a definition of the question to be posed, sufficient methodological detail to allow assessment of the viability of the project, a clear timeline and a definition of the likely deliverables. A full justification for the sum requested must accompany the application.

- A report on the progress of the research should be presented within one year of the award and at the end of the project. The grant must be used within two years from the date of award, and balance sheets must be forwarded annually. These should be sent to the Administrator. Any remaining funds after two years must be returned.

- It is anticipated that the work stemming from the project will be presented at one of COPE's annual seminar meetings within 2-3 years of the award. Such data may also be published in peer-reviewed journals. Any publications or related presentations at meetings by the recipient emanating in part or whole from COPE's support should be duly acknowledged and copies sent to the Administrator.

Applications are reviewed by a COPE sub-committee. Applicants will be advised of a decision as soon as practicable after the deadline date.

An application form can be obtained by contacting Linda Gough, COPE administrator, at LGough@ bmj.com or 0207383 6602. For more information on COPE, see http://www.publicationethics.org.uk/

The closing date for receipt of applications is 1 December 2007 or 1 June 2008. 